\title{
Can Technology Improve Health Literacy?
}

\section{Catherine A Wickham ${ }^{1}$ and Elena T Carbone ${ }^{2 *}$}

${ }^{1}$ Department of Nutrition, Chenoweth Lab, 100 Holdsworth Way, Amherst, MA01003, USA

${ }^{2}$ Associate Professor/Graduate Program Director, Department of Nutrition, Chenoweth Lab, Holdsworth Way, USA

Nearly nine out of 10 Americans have low health literacy skills [1]. This is a significant public health concern, as a low health literacy level can negatively impact an individual's ability to navigate the healthcare system, manage chronic diseases, follow a healthy diet, monitor medication, and read educational materials [2-4]. This raises the question: How can we minimize the potentially negative impact of low health literacy on health outcomes? The 2013 Institute of Medicine (IOM) report on health literacy identified technology as a key facilitator in bridging the gap between literacy and health outcomes [5]. Perhaps technology can provide some answers.

Health literacy is defined by the IOM as: "the degree to which individuals have the capacity to obtain, process, and understand basic health information and services needed to make appropriate health decisions" [2]. Low health literacy is a stronger predictor of health than age, income, employment status, education level, or race [6]. Health literacy is comprised of numerous skills, including reading and writing (print literacy), basic mathematical calculations (numeracy), and learning and speaking (oral literacy) [2]. To this basic definition, one can also add Electronic Health (eHealth) literacy skills, which are defined as: "The ability to seek, find, understand, and appraise health information from electronic sources and apply the knowledge gained to addressing or solving a health problem" [7]. Computer and technology literacy is a component of eHealth related to the use of these mediums to search for and use health information or to solve healthrelated problems [7]. eHealth literacy, computer literacy specifically, are increasingly important constructs given the rapid development of computer- and cell phone-mediated health programs.

In the United States, an estimated $85 \%$ of adults and $95 \%$ of adolescents 12-17 years old use the Internet [8,9]. Almost threequarters $(71 \%)$ of adults have used the Internet to search for healthrelated information and $21 \%$ have used some form of technology to track health information [10,11]. [10,11]. Most adults (91\%) and 78\% of adolescents in the US aged 12-17 years own a cell phone and 55\% and $47 \%$, respectively own a Smartphone [8,9]. As of 2012, $19 \%$ of cell phone users indicated they downloaded an app to help manage or track their healthcare [12]. Internet and cell phone usage is increasing around the world, and particularly in developing countries [13]. In 2008 , developing countries accounted for $52 \%$ of the share of Internet users; in 2013, that number rose to $65 \%$ [13]. Cell phone usage has seen even greater growth. In 2005, developing countries accounted for $55 \%$ of cell phone subscriptions worldwide; as of 2013 that number was over $77 \%$ [13]. The Internet and cell phones are poised to provide worldwide access to healthcare information.

Technology, in various forms, has become part of the fabric of the healthcare continuum. It can be a delivery system connecting remote, inaccessible areas and populations to health services and expertise; it can also be a form of assessment and reporting and can capture information from across a city block or around the world.. Technology can be used to aid diagnosis or provide specific healthcare treatment, or more broadly, to gather monitoring and surveillance data [14]. Technology can also be used to provide targeted information by standardizing automated educational messages across programs and by providing text messages tailored to individual needs and health conditions $[14,15]$.
One emerging area of study is the use of technology to assist with weight loss. Indeed, a recent PubMed search for the terms "technology (+) weight loss interventions" resulted in 112 studies. Of these, more than half $(63 \%)$ were published in the last five years. Because weight loss and weight maintenance require reading and numeric calculations to estimate portion sizes or to keep a diet record, it is not surprising that evidence suggests a relationship between health literacy and overweight/ obesity. For instance, low numeracy skills have been associated with higher Body Mass Index (BMI) levels among adults [16]. An inverse relationship has also been found between health literacy and weight in children and adolescents $[17,18]$. In a 2010 report commissioned by the American Heart Association to review the use of new and emerging strategies in weight loss, health literacy was identified as a key factor to consider when designing and developing technology-based weight loss interventions [19].

There is a paucity of data examining the impact of technology on health literacy. This will be a critical area to monitor in the future as the use of technology expands. The potential of technology-particularly cell phones and the Internet-lie in their acceptability and accessibility to increasingly broader segments of the population. Can technology improve health literacy? This may be the wrong question to ask at this point in our understanding of the field. Perhaps the question we should explore is: What role does health literacy play in the use of technologybased interventions to improve health? As data emerge to address this and other intervening questions regarding the intersection of health literacy, technology, and health outcomes, we are moving closer to discovering the answers we need.

\section{References}

1. Kutner M, Greenberg E, Jin Y, Paulsen C (2006) The health literacy of America's adults: Results from the 2003 National Assessment of Adult Literacy (NCES 2006-483). U.S. Department of Education, National Center for Education Statistics, Washington, DC

2. Nielsen-Bohlman L, Panzer AM, Kindig DA (2004) Health literacy: a prescription to end confusion. The National Academy Press Washington, DC.

3. Rudd RE, Keller DB (2009) Health literacy: new developments and research Journal of Communication in Healthcare 2: 240-257.

4. van der Heide I, Wang J, Droomers M, Spreeuwenberg P, Rademakers J, et al (2013) The relationship between health, education, and health literacy: results from the Dutch Adult Literacy and Life Skills Survey. J Health Commun 18: 172-184.

5. National Research Council (2013) Health literacy: improving health, health systems, and health policy around the world: workshop summary The National Academies Press Washington, DC.

*Corresponding author: Elena T Carbone, Associate Professor/Graduate Program Director, Department of Nutrition, Chenoweth Lab, Holdsworth Way, USA Tel: 413-545-1071; E-mail: ecarbone@nutrition.umass.edu

Received November 01, 2013; Accepted November 09, 2013; Published November 13, 2013

Citation: Wickham C, Carbone ET (2013) Can Technology Improve Health Literacy? J Nutr Disorders Ther 3: e114. doi:10.4172/2161-0509.1000e114

Copyright: (c 2013 Wickham C, et al. This is an open-access article distributed under the terms of the Creative Commons Attribution License, which permits unrestricted use, distribution, and reproduction in any medium, provided the original author and source are credited. 
6. Parker RM, Williams MV, Weiss BD, Baker DW, Davis TC, et al. (1999) Health literacy: report on the Council on Scientific Affairs. Ad Hoc Committee on Health Literacy for the Council on Scientific Affairs, American Medical Association. JAMA 281: 552-557.

7. Norman CD, Skinner HA (2006) eHealth literacy: essential skills for consumer health in a networked world. Journal of Medical Internet Research 8: e9.

8. http://www.pewinternet.org/Trend-Data-(Adults)/Whos-Online.aspx.

9. http://www.pewinternet.org/ /media//Files/Reports/2013/PIP_TeensandTechnology2013.pdf.

10. http://www.pewinternet.org/ /media//Files/Reports/PIP_HealthOnline.pdf.

11. http://www. pewinternet.org/ /media//Files/Reports/2013/PIP_TrackingforHealth\%20with\%20appendix.pdf.

12. http://www.pewinternet.org/ /media//Files/Reports/2012/PIP_MobileHealth2012_FINAL.pdf.
13. http://www.itu.int/en/ITU-D/Statistics/Pages/stat/default.aspx.

14. http://www.k4health.org/toolkits/mhealth/scaling-mobile-health-elementsnecessary-successful-scale-mhealth-developing.

15. National Research Council (2011) Innovations in health literacy research: workshop summary. The National Academies Press Washington, DC.

16. Huizinga MM, Beech BM, Cavanaugh KL, Elasy TA, Rothman RL (2008) Low numeracy skills are associated with higher BMI. Obesity 16: 1966-1968.

17. Chari R, Warsh J, Ketterer T, Hossain J, Sharif I (2013) Association between health literacy and child and adolescent obesity. Patient Educ Couns doi 10.1016/j.pec.2013.09.006.

18. Sharif I, Blank AE (2010) Relationship between child health literacy and body mass index in overweight children. Patient Educ Couns 79: 43-48.

19. Rao G, Burke LE, Spring BJ, Ewing LJ, Turk M, et al. (2011) New and emerging weight management strategies for busy ambulatory settings: a scientific statement from the American Heart Association endorsed by the Society of Behavioral Medicine. Circulation 124: 1182-1203. 